\title{
Origem do reflexo estético, mundanidade e considerações preliminares sobre a obra de arte na Estética (1963) de György Lukács
}

Renata Altenfelder Garcia Gallo ${ }^{1}$

\section{Resumo:}

A partir da descrição das noções de reflexo artístico e de mundanidade na estética de maturidade de György Lukács, este estudo pretende apresentar algumas questões preliminares acerca do que vem a ser a obra de arte, suas particularidades e seus pressupostos na Estética (1963), com o intuito de ressaltar, por fim, o caráter absolutamente humanista dessa obra lukacsiana.

Palavras-chave: György Lukács; estética; humanismo.

\section{Origin of the aesthetic reflex, worldliness and preliminary considerations about the work of art in Aesthetics (1963) by Gyorgy Lukacs}

\begin{abstract}
:
Based on the description of the concepts of reflexo artístico and mundanidade presented in Gyorgy Lukacs' Aesthetics (1963), this study aims to offer some preliminary considerations about what is a work of art, its particularities and assumptions, in order to emphasize the profound humanistic trace of this work.
\end{abstract}

Keywords: Gyorgy Lukacs; aesthetics; humanism.

\section{Introdução}

Ao longo de seus últimos 15 anos de vida, Lukács centralizou os seus esforços na redação de duas obras consideradas sínteses de sua trajetória intelectual: a Estética, que veio a público em 1963 e A ontologia do ser social, cuja conclusão data, aproximadamente, de 1968. Apesar de ter iniciado a escrita da Estética um pouco antes de 1956, o autor teve de suspender o projeto por causa de acontecimentos políticos na Hungria. Devido a tais episódios, no

\footnotetext{
${ }^{1}$ Doutora em Teoria e História Literária pela Universidade Estadual de Campinas (Unicamp) e professora do curso de Letras e Publicidade da PUC-Campinas e do Colégio Técnico de Campinas/Unicamp.E-mail: renataag@unicamp.br
} 
inverno de 1956, Lukács seguiu para a Romênia na companhia de políticos que protagonizaram o outono húngaro de 1956, dentre os quais estava Imre Nagy, de quem fora ministro da educação. Contudo, em abril de 1957, ao retornar a Budapeste, o filósofo retomou a redação do texto e, em menos de três anos, escreveu as mais de 1700 páginas que compõem a obra.

Sobre a sua publicação, afirmou para Tertulian a incrível dificuldade de obter uma autorização para o envio da obra ao seu editor alemão; bem como confessou que a publicação da Estética, na Alemanha Federal, só ocorreria, à época, com a condição de que ele deixasse a Hungria. A respeito da recepção do texto, Tertulian afirma que sua publicação, pela Luchterhand Verlag, em 1963, não provocou: "os grandes ecos que poderiam ser esperados" (TERTULIAN, 2008, p. 291); o que pode ser igualmente notado até os dias de hoje, se observarmos a circulação ainda incipiente do pensamento estético do autor.

Ainda sobre a recepção da Estética, um dos primeiros pensadores a se pronunciar publicamente sobre a obra foi George Steiner. Em junho de 1964, publicou, no Times Literary Supplement, uma das primeiras resenhas acerca do texto, assinalando, categoricamente, a relevância da obra. Ao obter conhecimento da resenha de Steiner, Lukács lhe endereçou uma carta em que dizia que as questões suscitadas pela estética permaneciam abertas para o futuro, asseverando a necessidade de um tempo longo de incubação da obra.

Ao refletir sobre o cenário da recepção das obras lukacsianas, especialmente no que tange à estética de maturidade, Tertulian afirma que Lukács se via como "um pensador de uma "época de transição", cujo trabalho teórico era inevitavelmente marcado por tentativas e incertezas" (TERTULIAN, 2008, p. 292). Esse momento de transição é compreendido a partir da perspectiva de uma acentuada crise dos antigos valores - tanto daqueles concernentes ao Ocidente capitalista como daqueles voltados ao socialismo a Stálin -, somada à crise de uma insurgência incerta de novos valores. Tertulian diz que, motivado por essa conjuntura, Lukács entende como necessário o questionamento aos artistas sobre o modo que refletem o homem e o mundo. Certamente, este é um dos elementos motivadores da redação da Estética, o que conduz Tertulian a afirmar que a tônica do pensamento estético lukacsiano reside na "defesa da integridade humana, partindo de uma imagem muito exigente do que é a substância humana" (TERTULIAN, 2008, p. 295).

Assim que iniciou o seu projeto estético de maturidade, Lukács pretendia a redação de uma obra que se organizaria em duas partes. Contudo, os seus planos originais sofreram modificações, pois a completude do texto só se realizaria com a redação de um terceiro tomo. Originalmente, a primeira parte se ocuparia da particularidade do fato estético e, em um segundo momento, o texto se ateria aos problemas do reflexo estético, tomando por 
objeto a estrutura da obra de arte e a tipologia filosófica do comportamento estético. Por fim, a terceira parte discutiria a questão da arte como fenômeno histórico-social. Entretanto, Lukács, já octogenário, conseguiu finalizar, somente, a primeira parte da Estética, publicada, então, em 1963.

Dentre as diversas noções que perpassam a obra, uma delas é a de que a vivência estética é oriunda de um processo histórico evolutivo, isto é, foi necessário um longo desenvolvimento humano para que o homem adquirisse a capacidade de produzir objetos artísticos e a competência de fruí-los. A fim de entender essa questão, é indispensável uma investigação sobre a origem do reflexo estético, temática sobre a qual nos debruçaremos no início deste estudo.

A partir da compreensão desse tipo de reflexo, voltaremos os nossos esforços para a descrição da noção lukacsiana de mundanidade na esfera artística. Afinal, se a obra de arte reflete o mundo próprio dos homens e é um objeto em que as possibilidades e potencialidades concretas do mundo e dos sujeitos se colocam frente ao receptor com a mais ampla profundidade, a mundanidade deve ser compreendida como uma característica própria da esfera estética.

Percorrido o caminho das representações artísticas rumo à mundanidade e diante do entendimento de que esta é um atributo da esfera estética, delinearemos, por conseguinte, algumas questões preliminares sobre o que vem a ser a obra de arte, suas particularidades e seus pressupostos na Estética (1963). Desta feita, pretendemos endossar o caráter absolutamente humanista da estética de maturidade de Lukács.

\section{Reflexo estético}

A leitura da estética lukacsiana, de antemão, deixa claro para o seu leitor que as investigações relativas ao fenômeno artístico não podem versar, apenas, sobre a compreensão de elementos que mais corriqueiramente são descritos nas estéticas, como a questão da forma artística ou da fenomenologia da recepção e da criação das obras de arte. Para Lukács, é importante entender, sobretudo, a gênese do reflexo e as especificidades relativas aos reflexos estético e científico, de modo que este se torna o tema central da primeira parte da Estética.

Segundo Lukács, arte e ciência são reflexos próprios do homem e têm como função possibilitar aos sujeitos conhecer o mundo que os circunda e, por conseguinte, fazer com que esses indivíduos possam dominá-lo. Nesse sentido, a estética de maturidade lukacsiana assume como pressuposto que a esfera da vida cotidiana é o plano de onde parte e o ponto para onde retornam os efeitos das objetivações humanas, pois é da vida cotidiana que:

provém a necessidade de o homem objetivar-se, ir além de seus 
limites habituais; e é para a vida cotidiana que retornam os produtos de suas objetivações. Com isso, a vida social dos homens é permanentemente enriquecida com as aquisições advindas das conquistas da arte e da ciência (FREDERICO, 2000, p. 303).

Conforme mencionamos, o reflexo artístico e o reflexo científico se alimentam da realidade cotidiana e refletem-na, o que motiva Lukács a afirmar que o comportamento cotidiano dos sujeitos é, igualmente, o começo e o fim de toda ação humana. Para ilustrar essa perspectiva, o autor constrói uma analogia entre o rio de Heráclito e o plano da vida cotidiana. Nesse sentido, o cotidiano assume a forma do rio, que se mantém em seu permanente fluxo onde tudo se movimenta e se transforma -, embora tudo retorne, sempre, ao seu leito. É assim, também, com o com a esfera do cotidiano, pois dela se depreendem, em formas superiores de recepção e de reprodução da realidade, a arte e a ciência; esferas que se diferenciam e que se organizam de acordo com suas próprias finalidades. Neste movimento, arte e ciência alcançam sua forma pura, que nasce das necessidades da vida social, para, em consequência de seus efeitos, isto é, de sua influência na vida dos homens, desembocar, novamente, na corrente da vida cotidiana.

O reflexo artístico e o científico funcionam como polos de recepção subjetiva do mundo e como momentos do mesmo processo de desenvolvimento histórico e social da humanidade, entretanto, há distinções marcantes entre ambos. Dentre elas, podemos destacar que a esfera artística tem como peculiaridade receber forma no particular e o reflexo científico, por sua vez, recebe forma através do universal ou do singular. Isto é, a ciência deve perseguir as determinações gerais do objeto a que se propõe a investigar enquanto a arte deve se orientar exclusivamente a um objeto particular:

A generalização estética realiza-se, portanto, na intensificação do traço individual, que assim caracterizado expressa no objeto da arte sua entificação especial, particular, única e, por isso mesmo, universal. (COSTA, 2012, p. 81)

O elemento que define a esfera estética como um tipo específico de reflexo é a capacidade de representação da realidade, de modo que aparência e essência sejam reveladas, conjuntamente, em sua imediaticidade e de maneira sensível. Isto é, aparência e essência se manifestam unidas e de forma harmônica no reflexo artístico, em uma determinada representação sensível. Essa adequação e coincidência entre essência e aparência não ocorre no reflexo científico.

$\mathrm{Na}$ esfera artística, percebe-se a constituição de um mundo próprio, o que não se verifica na esfera da ciência, em cuja o conhecimento é entendido como um processo no qual cada nova descoberta invalida a anterior ou a supera. No campo da arte, o objeto estético não é invalidado ou ameaçado quando surgem outras obras, essencialmente, porque são mundos próprios 
que não dependem de outros para existir. Por conseguinte, pode-se afirmar que a arte reflete uma totalidade intensiva da vida, ou seja, ela é "uma totalidade fechada que figura de modo concentrado o mundo dos homens num contexto particular" (FREDERICO, 1997, p. 62). Se a arte reflete a totalidade intensiva da vida, o mesmo não ocorre com a ciência, que procura refletir a totalidade extensiva da vida, visto que "o cientista busca refletir o infinito, o universo em seu conjunto” (FREDERICO, 1997, p. 61).

Ainda sobre as especificidades do reflexo estético e do científico, Lukács assegura que a individualidade da obra de arte é sempre determinada pela subjetividade de seu criador, ao passo que as proposições científicas encontram-se desvinculadas de qualquer momento subjetivo em sua origem, podendo, apenas, de acordo com Patriota:

cumprir a finalidade que lhe foi destinada socialmente se capta a realidade em sua legalidade ou essencialidade, depurando-a ao máximo de condicionamentos subjetivos e formando, através de conceitos, uma cadeia de determinações generalizadoras (PATRIOTA, 2010, p. 18).

Por esse motivo, afirma-se que o reflexo científico é marcado por seu caráter desantropomorfizador, pois a sua finalidade é o conhecimento da realidade objetiva, levando à consciência seus conteúdos, suas categorias etc., ao passo que a arte carrega como marca um caráter antropomorfizador, pois liga a objetividade à subjetividade, a essência ao fenômeno, aproximando, assim, os contrários. Nesse sentido, afirma-se que o reflexo artístico atua por meio de um movimento contrário ao reflexo científico, pois a sua projeção é marcada por um movimento de dentro para fora. Sendo assim, a arte opera sobre o sujeito enquanto a ciência age através de leis próprias, de forma que, no reflexo científico, a realidade objetiva independe da consciência e transforma em propriedades da consciência humana uma realidade que independe da consciência do homem. Na arte, contrariamente, é alcançada a unidade do sujeito individual com o objeto, de modo que nesta esfera o homem está implicado como objeto e como sujeito, o que corrobora a ideia de que não há mundo artístico sem um sujeito criador e um fruidor. Esse processo resulta que a obra de arte, embora seja uma coisa "em-si”, é, a um só passo, um "paranós”, pois nela está sempre contido o sujeito criador e o fruidor.

Deve-se ressaltar, portanto, que a autoconsciência do sujeito fruidor não está dissociada do mundo exterior; o que conduz à afirmação de Lukács de que as reproduções artísticas da realidade transformam o ser-em-si da objetividade em um ser-para-nós do mundo, representado na individualidade de cada totalidade intensiva que é a obra de arte. Essa propriedade estética amplia, alarga e aprofunda a consciência do homem sobre a natureza, sobre a sua condição humana, sobre a história e a sociedade. É no domínio da estética e, através da mediação entre as obras de arte e o sujeito, que o indivíduo pode 
se transformar de homem como um todo em sujeito plenamente humano, mantendo-se ao nível do gênero de maneira autoconsciente.

A polarização entre autoconsciência (arte) e consciência (ciência) é um elemento que distingue, também, os dois tipos de reflexo, todavia, é importante ressaltar que essa polarização é um resultado de um processo histórico, visto que o reflexo científico e o artístico nascem como que misturados. É objeto de o materialismo dialético investigar as condições históricas sob as quais se desenvolveu essa polarização. Nesse sentido, a nossa discussão se volta ao mapeamento da origem do reflexo estético e à sua relação com a categoria da mimese artística, aspectos fundamentais para a compreensão do fenômeno estético em sua relação com o desenvolvimento do gênero humano.

Lukács afirma que a arte se define pelo processo de imitação, isto é, pela mimese, cujo papel consiste na "conversão de um reflexo de um fenômeno da realidade na prática de um sujeito” (LUKÁCS, 1972, p. 7). A validade da imitação é um elemento universal na vida dos seres dotados de alto grau de organização, pois a conservação e a transmissão de experiências entre seres de uma mesma espécie não podem se consumar a não ser pela imitação; procedimento responsável por fixar os reflexos condicionados. Pensemos, por exemplo, na conservação das espécies de pássaros - como as andorinhas - que têm de migrar para garantir a sua sobrevivência. Se as espécies mais jovens não seguirem o modelo de migração das mais experientes, possivelmente sucumbirão ao frio e às adversidades impostas por parte das estações do ano que não lhes oferece um ambiente adequado à sobrevivência.

Quanto aos homens mais primitivos, o movimento de captação da realidade requeria, ao menos, uma aproximação elementar e consciente voltada para essa mesma realidade. O peculiar caráter subjetivo da seleção dessa realidade refletida tem que conter, em si, uma tendência à objetividade autêntica, processo que se realiza por meio da distinção dos conteúdos essenciais e inessenciais do reflexo. O princípio de seleção desses conteúdos é orientado pelos interesses vitais do homem, ou seja, quanto mais um conteúdo remete a tais interesses, maior a sua essencialidade. Sendo assim, se o reflexo não afetar um momento essencial da vida humana, a finalidade subjetiva do homem não se realiza - o que conduz à afirmação lukacsiana de que a práxis se impõe como critério de verdade para a captação da realidade a partir da seleção dos conteúdos do reflexo. No interno deste processo, é importante destacarmos o papel essencial do trabalho:

pois o progresso e o desenvolvimento do homem só são possíveis pela prática, pelo trabalho, de modo que ambos pressupõem, por sua vez, um reflexo mais correto e mais rico da realidade (LUKÁCS, 1972, p. 31, tradução nossa). 
Por meio do trabalho, o homem suspende a imediaticidade da vida cotidiana para tentar investigar a realidade objetiva tal qual ela é. Essa realidade comporta em si um movimento dialético de essência e aparência, o que ressalta, ao mesmo tempo, o seu aspecto contraditório e unitário. Sendo assim, todo o comportamento prático e intelectual dos homens, bem como o reflexo humano, deve se adequar a essa realidade. Tal argumentação dá margem ao debate sobre a prática artística do naturalismo. Se a vida cotidiana comporta em si um movimento dialético, que se consolida como elemento básico da vida, o reflexo artístico não pode ignorar esse movimento, tal como o faz o método naturalista de composição artística. Essa prática tende, segundo Lukács, a dissolver a contraposição e a diferenciação entre essência e aparência da realidade, de modo a anulá-las. Nesse sentido, o naturalismo seria uma tendência tardia na evolução histórica da humanidade, de modo que essa prática pretende

aproximar-se dos fenômenos aparentes e superficiais da vida cotidiana e eliminar, de forma mais radical possível, todas as categorias de mediação que apontam para os fenômenos essenciais da realidade (LUKÁCS, 1972, p. 22, tradução nossa).

Essa tendência à eliminação dos conteúdos essenciais da vida cotidiana surge somente, segundo Lukács, quando determinadas classes sociais esboçam temor em relação à descoberta desses conteúdos. Daí a afirmação do autor a respeito do aparecimento tardio dessa tendência artística, a qual expressa desorientação e caminha para o encerramento das perspectivas de desvelamento dos conteúdos aparentes; aspectos que contribuem à tendência fetichista do capitalismo.

O empenho de Lukács em compreender as especificidades do reflexo estético conduz o autor à discussão da relação intrínseca entre arte e magia, uma vez que a gênese do reflexo artístico só pode acontecer quando a intenção estética já se apresenta consolidada e arraigada na vida subjetiva dos homens. Somente a partir deste movimento podem ser percebidos como estéticos os processos cuja intenção inicial não tinha essa finalidade. Para o filósofo, algumas distinções são notáveis quando mencionados os termos arte, magia e religião; apesar dessas esferas partilharem de um princípio comum: o seu caráter antropomorfizador.

Tais atividades humanas congregam um potencial de conectar a objetividade à subjetividade, a essência ao fenômeno, aproximando, assim, polos contrários. Entretanto, há distinções que delimitam tais campos. Se, na esfera estética, a imagem refletida da realidade é percebida e compreendida como reflexo; às esferas da religião e da magia atribui-se uma realidade objetiva ao sistema de seus reflexos, de modo que se exige uma fé correspondente. No campo artístico, as obras de arte constituem um sistema 
fechado em si, que se refere, sempre, à realidade objetiva. Já o reflexo de natureza mágica ou religiosa se refere, sempre, a uma realidade transcendente.

Como mencionado, as formações artísticas são sempre reflexo da realidade objetiva e sua verdade e seu significado residem, essencialmente, na capacidade que esses reflexos possuem de captar corretamente a realidade, reproduzindo-a em sua forma verdadeira, de modo a evocar, no seu receptor, a imagem da realidade contida em tais reflexos. Essa orientação do reflexo estético volta-se para a cismundanidade da arte, que, segundo Lukács,

significa, de um modo imediato, que a ação evocadora daquilo que fora representado se orienta exclusivamente à recepção do sujeito, ou seja, que com o efeito evocador obtido, a formação mimética alcançou totalmente a sua finalidade (LUKÁCS, 1972, p. 45, tradução nossa).

Nesse sentido, a noção de cismundanidade assume como marca o antropocentrismo, pois evoca um sistema de pensamento que coloca o homem no centro do mundo, de forma que tudo a ele se refere. Apoiado nessa concepção, Lukács afirma que a autoconsciência da humanidade é a autêntica subjetividade portadora da arte. Se as obras de arte refletem de modo fiel os conteúdos da realidade objetiva, fazendo com que o receptor consiga evocálos, o processo de recepção artística passa a funcionar, por conseguinte, como um movimento de autoconsciência do fruidor, o que revela o caráter profundamente humanista da estética lukacsiana.

Essa autoconsciência, sobre a qual fizemos menção, só pode existir em um mundo onde o homem já tenha certo domínio do seu mundo interior e exterior. De acordo com Lukács, o sujeito primitivo não poderia ou não conseguiria dominar - no âmbito teórico ou prático - o mundo que o circundava. Essa configuração fez com que tal sujeito negligenciasse o mundo exterior para que pudesse empreender um movimento para "dentro", isto é, voltado à sua interioridade. Como este caminho não é natural, pois os instintos do homem o orientam para "fora", o indivíduo elimina as suas limitações através de meios artificiais.

Um dos exemplos resgatados pelo filósofo para retratar essa questão são os rituais dionisíacos. Embalados pelo uso de substâncias alucinógenas, ou ainda, pelos longos rituais dançantes, seus participantes empreendiam um caminho rumo à interioridade por meio de vias artificiais, configurando, assim, uma situação de êxtase. Para Lukács, a mimese e o êxtase são excludentes, a não ser quando aparecem simultaneamente, o que se verifica no período mágico. Suas formações miméticas são reflexos de fragmentos da vida e, não, de sua totalidade, apesar de essas mesmas formações tenderem a remontar essa totalidade. Nesse sentido, o êxtase proporcionado pelos rituais, por exemplo, tem como finalidade arrancar e arrebatar o sujeito da normalidade da vida, impondo a ele uma realidade transcendente que rompe 
com a normalidade e com a continuidade da vida cotidiana, gerando um comportamento que não se orienta à objetividade, à evocação e à recepção, elementos essenciais à conduta mimética.

Na vida cotidiana, a vinculação entre o evocador e o mimético tem como fundamento o desenvolvimento dos sentidos. Lukács ressalta dois aspectos essenciais sobre a questão. Um deles é a fantasia do movimento, ou seja, em uma peça de teatro, por exemplo, a imitação de um movimento pelo ator pode reproduzir evocativamente esse mesmo movimento na fantasia do espectador, de forma que, quanto mais desenvolvida e elaborada essa fantasia, maior a possibilidade de os homens se tornarem mais hábeis em suas ações cotidianas no que tange ao desenvolvimento desse movimento. $\mathrm{O}$ segundo aspecto enfatizado é a divisão do trabalho entre os sentidos, fator que se configura, igualmente, como um produto do trabalho. Para Lukács, o desenvolvimento dos sentidos na vida cotidiana é possível a partir da vinculação entre o evocador e o mimético, elementos fundamentais à esfera estética.

A vivência estética, oriunda de um processo histórico evolutivo, se configura, "como uma entrega imediata a um complexo unitário de imagens da realidade, as quais são refletidas sem que haja a ilusão de se estar diante da própria realidade" (LUKÁCS, 1972, p. 76, tradução nossa). Pensemos, por exemplo, em uma morte cênica. Nesse sentido, Lukács enfatiza que, na vida cotidiana, as erupções emocionais dos sujeitos possuem fundamentos objetivos, ao passo que, nas formações miméticas, não há uma realidade que suceda esses sentimentos na intenção de fundamentá-los. As emoções do fruidor podem ser suscitadas devido à orientação das imagens refletidas, as quais conduziram a evocação para uma direção específica. Essas considerações encaminham a argumentação do filósofo para a seguinte afirmação:

A forma artística surge como meio para expressar um conteúdo socialmente necessário, de tal modo que se produza um efeito evocador concreto e universal, que constitui também uma necessidade social. (LUKÁCS, 1972, p. 101, tradução nossa)

\section{O caminho da mundanidade}

Uma das peculiaridades das obras de arte é a criação de mundos autônomos, isto é, o objeto artístico reflete uma totalidade intensiva da vida, pois figura, de modo concentrado, o mundo dos homens em determinados contextos, entretanto um longo caminho do desenvolvimento humano teve de ser traçado para que adquiríssemos a capacidade de produzir obras de arte. Seguiremos descrevendo os traços mais essenciais desse desenvolvimento, segundo Lukács.

Primeiramente, o filósofo tece algumas considerações acerca das pinturas rupestres produzidas pelos caçadores no período paleolítico. Sobre 
elas, Lukács assinala um traço bastante curioso: apesar de apresentarem em si um traço amundanal (ausência de mundo), ainda assim apresentam certo realismo. Entende-se, assim, que essas figuras, normalmente reproduções de animais, não possuem qualquer ligação com elementos presentes em seu entorno, visto que são realizadas de modo "solto" no espaço em que foram produzidas. É, precisamente, nesse sentido que Lukács assinala a ausência de mundo dessas representações, apesar de apontar que elas reúnem um certo caráter realista. Pode parecer estranho este traço, entretanto ele se apresenta devido à alta capacidade de observação que esse homem do período Paleolítico possuía, pois a necessidade da caça, da pesca e da coleta em prol da sobrevivência fez com que essa habilidade - observação - fosse potencializada. Nesse sentido, devemos novamente ressaltar a noção de que tudo surge a partir da e na vida cotidiana. A habilidade estética dos povos caçadores do Paleolítico, ao reproduzir imagens individualizadas e típicas de animais surge, precisamente, de sua necessidade cotidiana de sobreviver.

Lembremos que essas pinturas rupestres tinham como finalidade, por exemplo, o logro na caça ou na pesca e não um êxito estético. Desse modo, essas reproduções obedecem a finalidades mágicas, impostas por uma determinação externa, que, neste caso, é a comunidade. Observando as condições de nascimento dessas pinturas bem como as suas finalidades, é altamente compreensível que os homens que produziram tais figuras se voltassem, somente, para a representação do animal que pretendiam caçar e, não, para questões estéticas. Sendo assim, não era necessário desenhar uma paisagem de fundo para abrigar a presa pretendida e incrementar, assim, aquela pintura, pois as finalidades deste homem não demandavam tal comportamento, exigiam, somente, a representação do animal para que impusessem sobre ele um domínio no momento da caça. Lukács sintetiza a questão:

O paradoxo das obras primas da pintura rupestre paleolítica consiste que os animais reproduzidos, considerados objetos soltos, parecem possuir aquela totalidade intensiva das determinações, ou seja, uma intenção de mundanidade, ao passo que, ao mesmo tempo, são representados isoladamente, em seu abstrato ser-parasi, como se a sua existência não interagisse com o espaço que imediatamente o rodeia, nem, ao menos, com o seu ambiente natural. Essas figuras estão - artisticamente - fora de todo o mundo, e sua configuração é em última instância amundanal (LUKÁCS, 1972, p. 126, tradução nossa).

Pelos motivos apontados por Lukács, a pintura paleolítica carrega em si uma situação contraditória, haja vista que magia e arte, em sua essência, se opõem: "aquela visa à consecução de finalidades materiais pela manipulação de forças transcendentes, essa visa à transformação da subjetividade do homem pela afirmação de sua terrenalidade" (PATRIOTA, 2010, p. 157). Se a 
pintura rupestre paleolítica ainda obedecia às finalidades da magia, carregando em sua estrutura uma contradição, a civilização grega será responsável por fazer com que tal paradoxo desapareça.

No decurso evolutivo da humanidade, a cultura grega representa o início da civilização, pois constrói, por meio de um processo autoconsciente, um mundo de acordo com as suas demandas, ampliando o domínio humano sobre as barreiras naturais, o que lhe confere certa segurança em seu estar no mundo. Nesse sentido, questões que nos parecem triviais, como a construção de casas seguras, diminui a hostilidade dos homens para com o mundo que habitam. Pensemos, desta feita, na construção de telhados e de muros voltados para a proteção desses sujeitos e para a amenização das ameaças externas ou naturais.

Se o alheamento entre sujeito e mundo diminui a partir do momento que o homem amplia o seu domínio em relação ao mundo, consequentemente, os indivíduos passam a reconhecer o seu entorno como algo que lhes corresponde, que lhe é familiar, e que pode ampliar, até certa medida, a sua própria personalidade. Surge, portanto, a concepção de um mundo como lar, ou melhor, como pátria. Essa nova conformação inaugura um tipo de representação artística voltado à mundanidade, o que permite uma evolução artística que desfaz o paradoxo das pinturas do paleolítico: amundanidade versus realismo. Ao se deparar com um novo contexto histórico filosófico, a arte teve de resolver, em sentido estético, os problemas apresentados pelas novas configurações históricas.

A partir do momento em que o homem se viu mais seguro em seu mundo, pois ampliou o seu domínio prático e intelectual sobre ele, a resposta artística a essa configuração foi a gênese do espaço pictórico, mais essencialmente, a necessidade de representação dos objetos unidos indissoluvelmente ao espaço que os rodeia, configurando, assim, uma interação vivia entre os objetos representados nas pinturas. Se este novo homem dominou o espaço que o rodeava; em suas representações pictóricas, a distribuição das cores, por exemplo, não poderia mais ocorrer de forma arbitrária, o que configurou uma revolução na sensibilidade humana. Para dar suporte a essa argumentação, Lukács retoma os resultados do trabalho do historiador austríaco Franz Wichoff (1853-1909):

A paisagem, com o céu em cima, o mar e os rios, o interior e o exterior dos edifícios, suas coberturas, as ferramentas, etc., não eram mais compreensíveis em sua conexão a não ser que fossem representados por meio de suas cores naturais, o que levava rapidamente à uma representação plenamente natural das figuras que se moviam naquele ambiente. (LUKÁCS, 1972, p. 138, tradução nossa) 
Essa interação entre os objetos presentes nas pinturas e a transição da cor fisiológica para a cor local são os elementos que marcam, segundo Lukács, a mundanidade. Foi aberta, assim, a possibilidade de construção de um mundo próprio e articulado que configura o reflexo artístico. A partir desse novo tipo de representação, a evocação artística de um mundo fechado pode ocorrer nas obras de arte. Sobre a questão, Patriota desenvolve afirma:

Em torno da categoria de "mundo próprio" aglomeram-se três determinações básicas. Em primeiro lugar, a conformação de uma realidade humanamente digna, própria do homem, em plena conformidade com suas carências e potencialidades, onde ser e dever ser não apenas se harmonizam, mas se apresentam numa identidade fática. Na obra de arte não há postulados, mas efetividades. O dever-ser é sempre ser efetivo. Em segundo lugar, este mundo se põe ao receptor como uma totalidade intensiva, totalidade que emana de dentro da moldura espaço-temporal da vida refigurada na obra. Cada obra de arte é vivida como um mundo em si completo. Em terceiro lugar, trata-se de um mundo próprio no sentido artístico, isto é, criado a partir de uma lógica estética autárquica. (PATRIOTA, 2010, p. 159)

Essa evolução artística, oriunda de uma alteração da quadratura histórica e filosófica de certo período da humanidade, é expressa pela capacidade do homem de articular objetos distintos, criando a imagem de uma totalidade orgânica e unitária de um todo. No âmbito estético, esse desenvolvimento encaminha as observações de Lukács para um aspecto basilar de sua Estética: os conteúdos selecionados pelos artistas para a criação de sua obra já indicam as possibilidades das realizações formais desse mesmo objeto artístico. Isso equivale a dizer que forma e conteúdo se condicionam e se determinam reciprocamente.

\section{Considerações iniciais sobre o objeto estético}

Para Lukács, o mundo refletido na da obra de arte comporta em si uma rica contradição, pois o objeto estético é uma totalidade intensiva, uma objetividade fechada em si, que independe do sujeito, ao mesmo tempo em que desnuda conteúdos essenciais relativos à vida humana. Para que essa contradição pudesse tomar forma, dois elementos recebem destaque: 1) a vida humana teve que se desenvolver a ponto de se converter em objeto de representação, isto é, em obra de arte; e 2) o homem pode se tornar um sujeito estético. No desenrolar deste estudo, expusemos, de acordo com Lukács, como o desenvolvimento humano se deu no sentido de que o homem pudesse se tornar um sujeito estético e como a vida humana se tornou objeto de representação. Desta feita, a contradição que a estrutura da obra de arte comporta - objetividade fechada em si, independente do sujeito, ao mesmo 
tempo em que revela conteúdos essenciais da vida humana - expõe um movimento de identidade absoluta de conteúdos externos e internos, que, a partir das determinações da forma artística, se convertem em uma unidade.

A conexão e a síntese desses conteúdos internos e externos é, para Lukács, a expressão imediata de um conteúdo ainda mais profundo: a verdade da vida, segundo a qual o homem conhece a si próprio à medida que conhece e domina o mundo que o cerca; espaço onde tem de viver e agir. Essa premissa da esfera estética impulsiona o sujeito ao autoconhecimento e ao conhecimento do mundo que o circunda, em um movimento circular. Ao retomar o conselho do Oráculo de Delfos aos antigos gregos, "conhece-te a ti mesmo", o marco inicial da longa trajetória da humanidade rumo ao autoconhecimento, Lukács nos coloca diante de sua compreensão da autêntica obra de arte, afirmando que ela impulsiona o ser humano a conhecer tudo aquilo que o rodeia - seus semelhantes, a sociedade em que vive, a natureza, o seu campo de ação etc. - ao mesmo tempo em que o coloca frente à compreensão dos estratos mais profundos do seu ser. Essa é, certamente, uma das maiores potencialidades da esfera estética.

A partir dessa reflexão, o filósofo afirma que o mundo particular das obras de arte não é utópico, objetiva ou subjetivamente falando, pois não aponta para algo transcendente, para além do homem ou do seu mundo. A arte compreende, portanto, o mundo próprio dos homens, carregando o seu traço de mundanidade. Ela é, ainda, um objeto em que as possibilidades e potencialidades concretas do mundo e do sujeito se colocam frente ao homem com a mais ampla profundidade. No âmbito estético, até as obras de arte que apontam ao receptor um mundo do dever são vividas pelo ser como seu mundo próprio. Nesse sentido, para Lukács, a canção mais idílica ou a natureza morta mais elementar expressam, em certa medida, um dever-ser que exige do sujeito da cotidianidade o alcance da unidade e da altura realizadas na obra de arte, movimento que configura o que o autor adjetiva de o dever de toda vida plena e autêntica.

Se a obra de arte possibilita ao homem o autoconhecimento e o conhecimento do mundo, ela compreende, ainda, o papel de objeto portador da memória da humanidade, pois materializa em si os conteúdos que ampliam, enriquecem e aprofundam a noção de homem e as relações deste com a natureza. Fruir um objeto estético é, portanto, um fenômeno que nos coloca diante dos destinos já vividos pela humanidade e dos feitos humanos, de modo que podemos nos conectar a eles e revivê-los em cada obra de arte, interiorizando, portanto, os caminhos passados e presentes dos homens, participando, destarte, da vida da humanidade. A fruição estética, enfim, preconiza a transformação de um passado espacial e temporal em um momento presente vivido, despertando, no sujeito fruidor, a consciência de viver em um mundo do qual ele faz parte e do qual é co-criador. 
É necessário, por conseguinte, enfatizar a questão da essencialidade da esfera estética em relação à memória, pois "a memória da humanidade não fixa mais do que o importante e não se sobrecarrega com o supérfluo” (LUKÁCS, 1972, p. 183, tradução nossa). Nesse sentido, os artistas devem selecionar os conteúdos essenciais para a criação da obra, procedimento que deve se realizar por meio de um movimento que impulsiona o artista a refletir, no objeto, situações e personagens típicos. As figuras que correspondem à formação dos tipos sociais são aquelas que congregam, em seu caráter, as relações que estão nascendo e as que já nasceram na história da humanidade, ou seja, os personagens ou situações típicas sintetizam as tensões sociais latentes de um período histórico em conexão com aquelas que já se materializaram. Essa compreensão da obra de arte não exige que todos os objetos estéticos tenham que refletir todo o conjunto de fenômenos de seu contexto de produção. Cada objeto artístico deve captar, reproduzir e refletir um conglomerado de situações, de destinos e de caracteres típicos que devem se converter em tema de representação, configurando, assim, uma universalidade em sentido intensivo. A comédia humana, de Balzac, é um exemplo que justifica a afirmação precedente, pois cada um dos livros que compõe essa obra representa um conjunto de tensões que nem sempre é o objeto de representação dos outros títulos.

A relação entre a produção estética e a essencialidade suscita uma compreensão da obra de arte como objeto que reflete a realidade de modo amplo e rico, corroborando a concepção do escritor e filósofo holandês François Hemsterhuis (1721-90) de que a alma humana tende, naturalmente, a se apropriar de um grande número de ideias no menor tempo possível. Transposto ao objeto estético, esse princípio determinará, para este autor, a noção de belo. Desta feita, a esfera estética é marcada pela capacidade de concentração e de intensificação, na obra de arte, dos conteúdos da realidade que o artista procura refletir. Lukács resgata as ideias de Hemsterhuis e afirma que o autor seria o precursor de manifestações importantes na esfera estética, como a divisão do trabalho dos sentidos e a formação de um meio homogêneo, bem como descreve de que forma ele entendia as finalidades da mimese.

Hemsterhuis compreende duas finalidades para a mimese artística. A primeira delas é a possibilidade objetiva de reprodução, na arte, dos objetos do mundo e a segunda consiste na garantia do potencial da arte de superação da natureza, de modo que não cabe ao objeto estético, somente, refletir a realidade, mas criar, sobretudo, uma imagem que ultrapasse a natureza em riqueza de determinações, criando efeitos que não podem ser por ela produzidos. Tais premissas asseguram a essencialidade das noções de concentração e de intensificação na esfera estética.

Se, para Lukács, Hemsterhuis entende o efeito da obra como superação da natureza, Nikolay Gavrilovich Tchernyshevsky (1828-89), filósofo, 
jornalista e escritor russo, trará outra contribuição importante à estética lukacsiana, a de que todas as reproduções artísticas da realidade - inclusive aquelas em que o conteúdo imediato é a natureza - têm como ponto mais significativo o homem. Tchernyshevsky acredita que a obra de arte deve figurar o metabolismo da sociedade com a natureza, o que conduz à noção lukacsiana de que cabe à obra levar ao sujeito cotidiano a natureza da objetividade da qual ele próprio participa. Nesse sentido, Lukács observa que, na Poética aristotélica, a expressão imitação da natureza não é utilizada, levando-o a proferir que, para Platão e Aristóteles, o verdadeiro conteúdo da arte não é a natureza, mas a própria vida dos homens. Assegura-se, assim, o caráter antropomorfizador da obra de arte. Apesar das importantes contribuições de Tchernyshevsky, Lukács assinala que suas noções não são mais do que intuições que desembocam em certo formalismo, pois o autor limita-se a adivinhar, sem reconhecer nem conhecer claramente a vinculação econômica da humanidade com a natureza.

A crítica de Lukács dirigida ao filósofo russo tem como ponto central a importância da vinculação econômica da história da humanidade ao seu desenvolvimento. Trocando em miúdos, a tônica dessa discussão recai na importância de se pensar os nexos que a categoria do trabalho - entendida no sentido marxiano do termo - possui com a esfera estética; o que conduz Patriota a afirmar que: "Todas as questões que surgem de dentro do mundo da arte encontram no princípio da humanização do homem pelo trabalho sua possibilidade efetiva de explicação" (PATRIOTA, 2010, p. 195). Na estética de maturidade, essa compreensão fundamentará a relação sujeito-objeto, de modo que o movimento da subjetividade em direção à esfera estética será elucidado a partir do resgate do processo metabólico do trabalho.

Passando por essa compreensão, Lukács adota a ideia de trabalho marxiana, compreendendo-o como o momento originário em que o homem exterioriza a sua subjetividade e aquilo que o é em seu interior. Dessa forma, o trabalho adquire o status de momento disparador do processo de interiorização dos indivíduos:

E com o trabalho, também a objetividade natural surge como determinação originária, pois o trabalho é a ação do sujeito frente a uma objetividade independente e inderivável. Segue-se daí que, pelo trabalho, o homem surge como sujeito e a natureza, que existe por si, como objeto deste sujeito. Em seu movimento concreto, esta relação sujeito-objeto é o processo de exteriorização do sujeito que age sobre a objetividade dada, um movimento duplo: a alienação deste sujeito de si mesmo e o retorno a si dessa alienação idêntico. (PATRIOTA, 2010, p. 191)

Ao agir no mundo, por meio do trabalho, o homem manifesta ativa e passivamente a sua generidade, pois busca uma utilidade social para o objeto por ele produzido. Nesse sentido, Lukács retoma a ideia de Marx, contida nos 
Manuscritos econômico-filosóficos (2004), de que o objeto do trabalho é a objetivação da vida genérica do homem, pois é, por meio dele, que o sujeito se duplica intelectualmente em sua consciência, contemplando-se em um mundo criado por ele próprio. No sentido oposto, o trabalho estranhado retira do homem o objeto por ele produzido, arrebatando-lhe a sua vida genérica, ou seja, sua real objetividade genérica. Ainda sobre a noção de trabalho marxiana, Jesus Ranieri afirma que:

É nesse texto [Manuscritos econômico-filosóficos] que o lugar do trabalho como forma efetivadora do ser social é realmente exposta e desenvolvida, algo que, até então, mesmo em Marx, não havia sido feito. É nele que o conjunto das esferas da existência humana (desde o lugar da arte, da religião, da filosofia, passando pela conceituação de liberdade, até as formas concretas e imediatas de realização do trabalho) aparece como dependente da esfera de produção - o trabalho é mediação entre homem e natureza, e dessa interação deriva todo o processo de formação humana. (RANIERI, 2004, p. 14)

Ao longo do processo de formação e de evolução da humanidade, o homem interage com a natureza e a transforma conforme as exigências da vida em sociedade. A culturização de antigos desertos é um exemplo de tal processo, que modifica e enriquece o homem e as suas relações com o ambiente e com os outros homens. A ideia de conformidade ou de adequação acerca da relação metabólica do homem com a natureza pode ser tomada no sentido de uma acepção prática, tal qual o exemplo citado, e em uma acepção voltada à atividade estética, segundo Tertulian. Devemos ter em mente que a estética de maturidade resgata a ideia de conformidade ao entender que a missão da arte consiste em "evocar a realidade em sua plena objetividade, mas da perspectiva única de sua conformidade com as exigências humanas" (TERTULIAN, 2008, p. 253). A acepção estética que Lukács pretende à ideia de conformidade é descrita da seguinte maneira por Tertulian:

como uma adequação do mundo (vista sob a forma de "troca material de substância entre natureza e sociedade") às exigências do homem tomado em sua essência humana, como sua conformidade com os atributos - equilíbrio ou perturbação, bem ou mal - da personalidade humana em sua integralidade (TERTULIAN, 2008, p. 253).

As considerações até aqui realizadas nos encaminham à afirmação de que o movimento da subjetividade em direção à esfera estética será elucidado por meio da retomada do processo metabólico do trabalho, de forma que os questionamentos suscitados sobre o mundo da arte devem ser explicados a partir do princípio do processo de humanização do homem, realizado por meio do trabalho. Diante dessa perspectiva, a estética de maturidade lukacsiana ao compreender que o sujeito, ao se relacionar com o entorno, passa a conhecer 
e dominar o mundo ao seu redor, bem como tem sua interioridade enriquecida - resgata a noção marxiana de que: "o conhecimento de si do homem não ocorre sem o conhecimento do conjunto de suas relações com o mundo" (TERTULIAN, 2008, p. 253). Dito de outro modo, Lukács assegura o elo e a correlação entre o ato de objetivação e o desenvolvimento da sensibilidade humana, o que, transposto à criação artística, conduz à afirmação de que a conexão estabelecida entre o conhecimento de si e o conhecimento do mundo está no alicerce do equilíbrio entre objetividade e subjetividade no momento da criação artística.

\section{A Estética e o seu traço humanista}

Como já aferimos ao longo deste estudo, a vivência estética é proveniente de um longo processo evolutivo da humanidade, isto é, a capacidade humana de produzir e de fruir objetos artísticos não surgiu "do nada”, mas de um acúmulo das experiências humanas a partir de sua relação com a natureza. Neste decurso temporal, o reflexo mágico e o reflexo artístico foram, gradualmente, se desprendendo, para que, assim, a criação das obras de arte se tornasse possível.

Ao investigar o fenômeno estético, Lukács afirma que os objetos artísticos autênticos criam mundos que refletem os conteúdos mais essenciais da vida humana, que falam sobre os homens e para os homens. Nesse diálogo, as obras de arte refletem as possibilidades e potencialidades concretas do mundo e dos homens, de modo que o fruidor pode receber esses conteúdos, mediados pela forma artística, com ampla profundidade.

Ao asseverar que as obras de arte refletem os conteúdos próprios da vida humana, Lukács identifica o seu traço de mundanidade. Nesse sentido, o percurso da evolução humana e dos objetos artísticos rumo à mundanidade evoca um sistema de pensamento antropocentrista, que coloca o homem no centro do mundo, de maneira que os mundos criados pelos artistas em suas obras encontram sempre o homem e sua vida como referência.

Ora, a humanitas - ou seja, o estudo apaixonado da natureza humana do homem - faz parte de toda a essência da literatura e de toda arte autêntica; daí que toda boa arte e toda boa literatura sejam humanistas, não só ao estudarem apaixonadamente o homem e a verdadeira essência da sua natureza humana, mas também por defenderem apaixonadamente a integridade humana do homem contra todas as tendências que a atacam, a envilecem e a adulteram. (LUKÁCS apud CARLI, 2012, p. 17)

Não é, entretanto, somente o mundo da obra de arte que congrega essa perspectiva humanista, mas os efeitos que provém, principalmente, de sua recepção. De acordo com Lukács, a arte autêntica, isto é, aquela denominada 
realista, possui uma missão desfetichizadora. Vejamos as considerações de Bastos sobre a questão:

\begin{abstract}
A arte ou é desfetichizadora ou não é arte. A isso Lukács chama realismo: em sua missão desfetichizadora, a arte representa situações de opressão, de degradação da humanidade do homem, mas as personagens aí representadas podem perceber essas situações como situações criadas pelos homens, não como próprias de uma condição humana antistórica, e se assim as percebem, percebem também as possibilidades de superá-las. (BASTOS, 2016, p. 48)
\end{abstract}

Ao assegurar a potência desfetichizadora da arte, Lukács garante, por conseguinte, a possibilidade de defesa da integridade da humanidade no plano da vida cotidiana. Tal movimento é possível, pois a relação sujeito-objeto, oriunda da fruição artística, possibilita ao receptor a percepção "natural" de alguns aspectos da vida, que, no plano disperso da cotidianidade, ficam obscurecidos. É nesse sentido que, ao fruir uma obra de arte, o sujeito pode ter os seus sentidos ampliados e renovados, o que o conduz para uma nova percepção do mundo objetivo.

Soma-se a isso o caráter profundamente social da obra de arte, visto que Lukács a compreende como portadora da memória da humanidade, pois ela reflete os destinos e os feitos dos homens. Ao assumir essa perspectiva, a vivência estética permite ao fruidor a evocação dessa memória bem como possibilita a conexão e a vivência do sujeito com os destinos típicos já vividos pela humanidade: esse movimento compreende uma recepção artística na qual o sujeito incorpora tanto os caminhos passados e presentes da evolução humana como a consciência dos homens que realizaram essas trajetórias. Ao sujeito estético, portanto, é ofertada a possibilidade de participação efetiva na vida da humanidade. Sobre esse movimento, também é necessário ressaltar a ideia de que a fruição estética possibilita a transformação de um passado espacial e temporal em um momento presente vivido, despertando, no receptor, a consciência de viver em um mundo do qual ele faz parte e do qual é, ainda, co-criador.

A implicação dessa experiência é a recepção e a apropriação pelo sujeito estético de um mundo com sentidos renovados, pois a sua psique se amplia e se enriquece a partir da captação desses novos conteúdos. Ao se reconhecer no mundo dos objetos e ao se sentir parte dele, o sujeito estético pode restabelecer a sua relação como o mundo objetivo, orientando suas práticas sociais para transformá-lo. Essa transformação existencial pode ser direcionada, por conseguinte, para a realização de possibilidades humanas autênticas, mais significativas, ricas e amplas. A vivência estética evoca, assim, a possibilidade de um desenvolvimento humano em que o sujeito, sem apagar a sua singularidade, reivindica para si as tarefas do gênero humano, vivenciando-as como suas e compreendendo os traços comuns da vida do gênero e de sua 
própria existência. É nesse sentido que afirmamos o traço marcadamente humanista da estética de maturidade de Lukács.

\section{Referências bibliográficas}

BASTOS, H. Ficcional e verídica (Notas sobre a historicidade da poesia). Revista Letras, Curitiba, UFPR, n. 94, pp. 87-103, jun./dez. 2016. Disponível em: <revistas.ufpr.br/letras/article/download/46090/30158>, acessado em: 2 jan. 2019.

COSTA, M. H. M. da. De como Lukács chegou à distinção entre alienação e estranhamento para depois abandoná-la. Verinotio - Revista on-line de Educação e Ciências Humanas, n. 14, ano VIII, p. 79-86, 2012.

FREDERICO. C. Lukács: um clássico do século XXI. São Paulo: Ed. Moderna, 1997.

. Cotidiano e arte em Lukács. Estudos Avançados, v. 14, n. 40, p. 299-

308, 2000. Disponível em: <dx.doi.org/101590/So10340142000000300022>, acessado em: 10 maio 2017.

CARLI, R. A estética de György Lukács e o triunfo do realismo na literatura. Rio de Janeiro: Editora da UFRJ, 2012.

LUKÁCS. G. Estetica v. 1. Barcelona: Grijalbo, 1974.

. Estetica v. 2. Barcelona: Grijalbo, 1972.

. Estetica v. 3. Barcelona: Grijalbo, 1967.

. Estetica v. 4. Barcelona: Grijalbo, 1967.

PATRIOTA, R. A relação sujeito-objeto na Estética de Georg Lukács: reformulação e desfecho de um projeto interrompido. Tese (Doutorado) defendida na Universidade Federal de Minas Gerais (UFMG), 2010.

RANIERI, J. Apresentação: sobre os chamados Manuscritos econômicofilosóficos de Karl Marx. In: MARX, K. Manuscritos econômico-filosóficos. Trad. Jesus Ranieri. São Paulo: Boitempo, 2004.

TERTULIAN, N. Lukács: etapas de seu pensamento estético. São Paulo: Unesp, 2008. 
Como citar:

GALLO, Renata Altenfelder Garcia. Origem do reflexo estético, mundanidade e considerações preliminares sobre a obra de arte na Estética (1963) de György Lukács. Verinotio - Revista on-line de Filosofia e Ciências Humanas, Rio das Ostras, v. 26, n. 1, pp. 106-25, jan./jun. 2020.

Data do envio: 27 fev. 2020

Data do aceite: 8 maio 2020

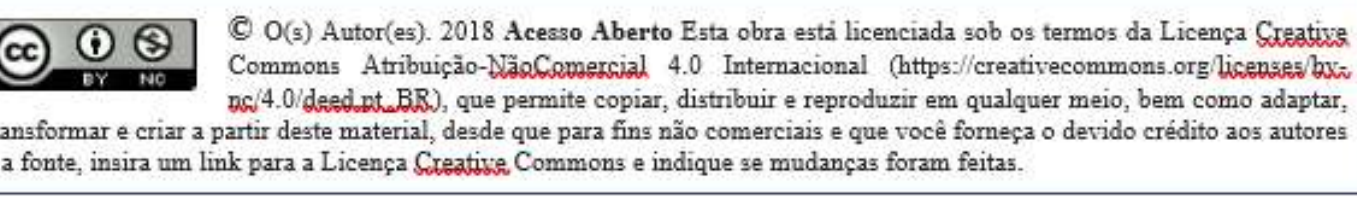

